\title{
中晚生カンキツ“不知火’の樹体生育と果実品質ならびに細根量に及ぼす土壌改良 資材と窒素施肥量の影響
}

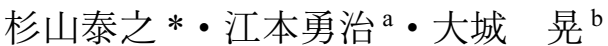 \\ 静岡県柑樀試験場４24-0905＼cjkstart静岡市清水区駒越西
}

\section{Effect of Soil Amendments and Nitrogen Fertilizer Application on Tree and Fine Root Growth and Fruit Quality of Medium-late Maturing Cultivar Citrus 'Shiranuhi'}

\author{
Yasuyuki Sugiyama*, Yuji Emoto ${ }^{\mathrm{a}}$ and Akira Ooshiro ${ }^{\mathrm{b}}$ \\ Shizuoka Prefctural Citrus Experiment Station, Shimizuku, Komagoenisi, Shizuoka 424-0905
}

\begin{abstract}
Effects of applying soil amendments and the rate of nitrogen fertilizer application on tree and fine root growth and fruit quality were surveyed in 'Shiranuhi' ['Kiyomi' (Citrus unshiu Marc. $\times$ C. sinensis Osb.) $\times$ C. reticulata Bla.], which shows weak vigor. Soil amendments (bark manure, peat-moss, perlite) were applied to improve the physical condition of the soil and to increase the number of fine roots. Excess supply of nitrogen suppressed fine root development, and enhanced the peel ratio and concentration of soluble solid (Brix) in fruits. The effect of an excess supply of nitrogen was about twice as strong as those obtained from the application of soil amendments. Applications of soil amendments and the conventional amount of fertilizer were necessary to improve tree vigor and the number of fine roots.
\end{abstract}

Key Words : bark manure, peat-moss, perlite, tree vigor

キーワード：バーク堆肥，ピートモス，パーライト，樹勢

\begin{abstract}
緒 言
中晚生カンキッの ‘不知火’ (“清見’ × ‘中野 3 号’ ポン カン）は糖度が高く，肉質佳良で，香りが良く，食べやす いことから，産地・市場・消費者の人気が高い.このため, 1990 年ころから, 熊本県をはじめ全国のカンキッ産地に急 速に広がり，1997 年からは品質の特に良いもの（糖度 13 度以上，酸度 $1.0 \%$ 以下）については, 商標登録名「デュポ ン」として, 市場に流通している（河瀬，1999a）。2001 年 の生産面積は $2,345 \mathrm{ha}$, 生産量は $27,927 \mathrm{t}$ であり, 年々増加 傾向である.
\end{abstract}

しかし，この品種は樹勢が弱いため，樹冠拡大が遅く， 新梢が枯死したり, 収量が不安定になったりするなど, 栽 培が難しい。 また，特に樹勢が弱い樹では果汁の酸度が高 くなりすぎるなどの問題点も確認されており，樹勢強化の ための様々な対策が行われてきた（平山ら，1996; 加美ら，

2005 年 8 月 15 日 受付. 2006 年 2 月 20 日 受理.

本報告の一部は園芸学会平成 15 年春季大会で発表した.

本研究は農林水産省助成事業（地域基幹農業技術体系化促進研

究）によって行われた.

* Corresponding author. E-mail: yasuyuki1_sugiyama@pref.shizuoka.lg.jp

a 現在 : 静岡県環境衛生科学研究所 $\mathrm{b}$ 退職
1998; 河瀬, 1999b).

また，生産現場では樹勢を強くし，収量を増加させたい ため，一部では多肥栽培が行われていた（岡島，1999）。

一方，樹勢の弱い園では，細根の少ないことが観察され

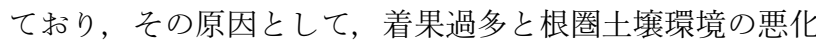
（過湿と乾燥，多肥による土塞溶液濃度の上昇，未熟堆肥施 用による硫化水素，メタンガス，一酸化炭素の発生，土㙋 物理性の悪化（気相率の減少））などが論じられてきた（河 瀬，1999b; 北園ら，2000; 高原， 1999）.

“不知火’は比較的新しい品種であることから，施肥試験 の報告は少なく，土壤改良資材と窒素施肥量とを組み合わ せた試験例はない。そこで，筆者らは ‘不知火’に対し， 土壤改良資材，窒素施肥量が，土壌物理性，細根量，樹体 生育，果実品質に及ぼす影響を調査した。その結果，“不知 火’の細根量を増加及び減少させる土壤改良資材と窒素施 肥量の組合せの知見が得られたので報告する.

\section{材料および方法}

供試樹は 1999 年 4 月に静岡県柑橘試験場内の無底 6 角形 コンクリート枠（面積: $6 \mathrm{~m}^{2}$, 土塞タイプ: 礫質灰色台地 土, 土性 : 埴壤土 $(\mathrm{CL})$, 土壌 $\mathrm{pH}: 5.0 \sim 5.4$ ) に $60 \mathrm{~L}$ ポッ トで育成した 5 年生 “不知火’（カラタチ台）を植栽し, 
第 1 表 供試要因と水準の内容

\begin{tabular}{|c|c|c|c|c|}
\hline 要因 & 第 1 水準 & 第 2 水準 & 第 3 水準 & 第 4 水準 \\
\hline A：土壌改良資材 ${ }^{z}$ & $\mathrm{~A}_{1}$ : バーク堆肥 $(50 \mathrm{t} / \mathrm{ha})$ & $\mathrm{A}_{2}:$ ピートモス $(8 \mathrm{t} / \mathrm{ha})$ & $\mathrm{A}_{3}:$ パーライト $(6 \mathrm{t} / \mathrm{ha})$ & $\mathrm{A}_{4}$ : 無施用 \\
\hline B : 窒素施肥量 & $\mathrm{B}_{1}$ : 半量 & $\mathrm{B}_{2}$ : 標準量 & $\mathrm{B}_{3}: 2$ 倍量 & $\mathrm{B}_{4}: 3$ 倍量 \\
\hline $\mathrm{C}$ : ゼオライト施用量 & $\mathrm{C}_{1}$ : 無施用 & $\mathrm{C}_{2}$ : 少 $(5 \mathrm{t} / \mathrm{ha})$ & $\mathrm{C}_{3}:$ 中 $(20 \mathrm{t} / \mathrm{ha})$ & $\mathrm{C}_{4}$ : 多 $(50 \mathrm{t} / \mathrm{ha})$ \\
\hline
\end{tabular}

$\mathrm{z}$ 植付け時（1999 年 4 月）施用量， $2000 \sim 2003$ 年の 2 月に植付け時の半量を施用

\begin{tabular}{|l|l|l|l|}
\hline 1 & 2 & 3 & 4 \\
$\mathrm{~A}_{4} \mathrm{~B}_{1} \mathrm{C}_{1}$ & $\mathrm{~A}_{1} \mathrm{~B}_{2} \mathrm{C}_{1}$ & $\mathrm{~A}_{2} \mathrm{~B}_{3} \mathrm{C}_{1}$ & $\mathrm{~A}_{3} \mathrm{~B}_{4} \mathrm{C}_{1}$ \\
\hline 5 & 6 & 7 & 8 \\
$\mathrm{~A}_{1} \mathrm{~B}_{1} \mathrm{C}_{2}$ & $\mathrm{~A}_{4} \mathrm{~B}_{2} \mathrm{C}_{2}$ & $\mathrm{~A}_{3} \mathrm{~B}_{3} \mathrm{C}_{2}$ & $\mathrm{~A}_{2} \mathrm{~B}_{4} \mathrm{C}_{2}$ \\
\hline 9 & 10 & 11 & 12 \\
$\mathrm{~A}_{2} \mathrm{~B}_{1} \mathrm{C}_{3}$ & $\mathrm{~A}_{3} \mathrm{~B}_{2} \mathrm{C}_{3}$ & $\mathrm{~A}_{1} \mathrm{~B}_{3} \mathrm{C}_{3}$ & $\mathrm{~A}_{4} \mathrm{~B}_{4} \mathrm{C}_{3}$ \\
\hline 13 & 14 & 15 & 16 \\
$\mathrm{~A}_{3} \mathrm{~B}_{1} \mathrm{C}_{4}$ & $\mathrm{~A}_{2} \mathrm{~B}_{2} \mathrm{C}_{4}$ & $\mathrm{~A}_{4} \mathrm{~B}_{3} \mathrm{C}_{4}$ & $\mathrm{~A}_{1} \mathrm{~B}_{4} \mathrm{C}_{4}$ \\
\hline
\end{tabular}

第 1 図 試験区処理の内容

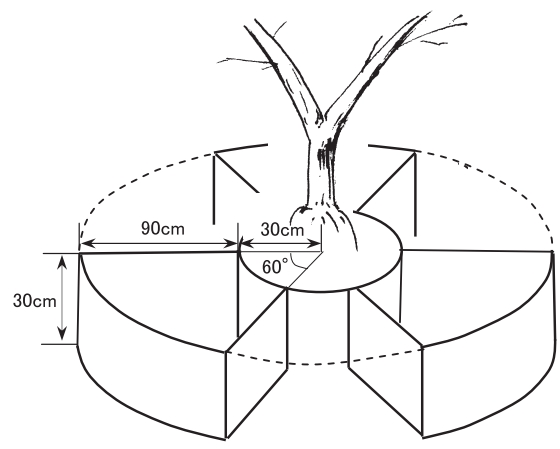

第 2 図 根量調査の堀上位置

第 2 表 異なる土䁃改良資材と窒素施肥量が土壌物理性に及ぼす影響（三相分布：pF1.5）

\begin{tabular}{|c|c|c|c|c|c|c|c|c|c|}
\hline \multirow{2}{*}{ 要 因 } & \multirow{2}{*}{ 水 準 } & \multicolumn{4}{|c|}{1 1 年目（1999 年） } & \multicolumn{4}{|c|}{4 4 年目（2002 年） } \\
\hline & & 仮比重 & 固相 ${ }^{z}$ & 液相 & 気相 & 仮比重 & 固相 & 液相 & 気相 \\
\hline \multirow{5}{*}{ A：土畩改良資材 } & & & $\%$ & $\%$ & $\%$ & & $\%$ & $\%$ & $\%$ \\
\hline & バーク堆肥 & $1.05 \mathrm{ab}^{\mathrm{y}}$ & $39.6 b$ & 17.3 & $43.2 \mathrm{a}$ & $1.14 \mathrm{~b}$ & $45.1 b$ & 21.5 & 33.4 \\
\hline & ピートモス & $1.00 \mathrm{~b}$ & $38.7 b$ & 17.1 & $44.3 \mathrm{a}$ & $1.17 \mathrm{~b}$ & $45.5 b$ & 21.9 & 32.6 \\
\hline & パーライト & $1.06 \mathrm{ab}$ & $42.8 \mathrm{ab}$ & 18.3 & $38.9 \mathrm{a}$ & $1.23 \mathrm{~b}$ & $47.9 \mathrm{~b}$ & 19.3 & 32.8 \\
\hline & 無施用 & $1.18 \mathrm{a}$ & $45.8 \mathrm{a}$ & 19.1 & $35.2 \mathrm{a}$ & $1.37 \mathrm{a}$ & $52.5 \mathrm{a}$ & 22.0 & 25.5 \\
\hline \multirow{4}{*}{ B：窒素施肥量 } & 半量 & 1.12 & 43.2 & 18.4 & 38.5 & 1.24 & 47.5 & 21.8 & 30.7 \\
\hline & 標準量 & 1.05 & 41.1 & 18.7 & 40.3 & 1.23 & 47.8 & 20.7 & 31.5 \\
\hline & 2 倍量 & 1.03 & 40.0 & 16.0 & 44.1 & 1.24 & 48.4 & 21.1 & 30.5 \\
\hline & 3 倍量 & 1.09 & 42.7 & 18.7 & 38.7 & 1.21 & 47.3 & 21.0 & 31.6 \\
\hline \multirow{4}{*}{ C : ゼオライト施用量 } & $\begin{array}{l}\text { 無施用 } \\
\end{array}$ & 1.11 & 40.7 & 17.4 & 41.9 & 1.23 & 48.3 & 24.6 & 27.1 \\
\hline & 少 & 1.04 & 43.0 & 20.3 & 36.8 & 1.23 & 48.0 & 20.3 & 31.7 \\
\hline & 中 & 1.11 & 40.2 & 16.6 & 43.2 & 1.22 & 46.9 & 18.7 & 34.4 \\
\hline & 多 & 1.05 & 43.0 & 17.5 & 39.6 & 1.24 & 47.8 & 21.1 & 31.1 \\
\hline \multirow{3}{*}{ 分散分析 ${ }^{x}$} & 土䁃改良資材 & $* *$ & $* *$ & n.s. & $*$ & $*$ & $*$ & n.s. & n.s. \\
\hline & 窒素施肥量 & n.s. & n.s. & n.s. & n.s. & n.s. & n.s. & n.s. & n.s. \\
\hline & ゼオライト量 & n.s. & n.s. & n.s. & $\triangle$ & n.s. & n.s. & n.s. & n.s. \\
\hline
\end{tabular}

${ }^{\mathrm{z}}$ 固相，液相，気相は， $\arcsin$ 変換した值について統計処理を行った

${ }^{\mathrm{y}}$ Tukey の多重検定により，同符号間には 5\%水準で有意差のないことを示す

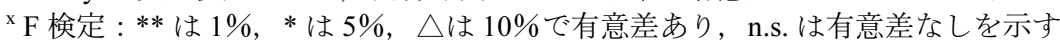

2003 年 3 月まで調査した.

供試した要因と水準は，A：土垬改良資材（バーク堆肥, ピートモス，パーライト，無施用)，B : 窒素施肥量 (半量, 標準量, 2 倍量, 3 倍量), C : ゼオライト施用量（無施用, 少，中，多）である (第 1 表)。本試験では，樹勢強化と根 量増加について 3 つの要因（土壤物理性, 窒素施肥量, 塩 基置換容量) 4 水準の処理区が必要であったこと, また, 供 試樹の数が限られていたこと等の理由から, 効率よく試験 を進めるため, 要因と水準をラテン方格法に割り付けて実
施した（第 1 図）.

年間窒素施肥量は，標準量区で 1 枠当たり 1999 年 : $90 \mathrm{~g}$ $(150 \mathrm{~kg} / \mathrm{ha}) ， 2000$ 年: $120 \mathrm{~g}(200 \mathrm{~kg} / \mathrm{ha}) ， 2001$ 年: $136 \mathrm{~g}$ $(227 \mathrm{~kg} / \mathrm{ha}), 2002$ 年 : $152 \mathrm{~g}(253 \mathrm{~kg} / \mathrm{ha})$ と供試樹の生育に したがって増施肥し，3 月，6月， 7 月， 8 月，10 月に硫酸 アンモニウムで年間窒素施肥量の $20 \%$ ずつを施用した. ま た,リン酸は窒素施肥量（標準量区）の50\%を重焼リンで, カリウムは窒素施肥量（標準量区）と同量を硫酸カリウム で，全処理区とも同一量を施用した. 
第 3 表＼cjkstart異なる土㙥改良資材と窒素施用量が樹体生育量に及ぼす影響

\begin{tabular}{|c|c|c|c|c|c|c|c|c|c|c|c|c|c|}
\hline \multirow{2}{*}{ 要 因 } & \multirow{2}{*}{ 水 準 } & \multicolumn{4}{|c|}{1999 年 4 月 30 日（植栽時） } & \multicolumn{4}{|c|}{2003 年 3 月 20 日 (植栽 4 年後) } & \multicolumn{4}{|c|}{ 増加量 } \\
\hline & & 幹周 & 樹幅 & 樹高 & 樹冠容積 & 幹周 & 樹幅 & 樹高 & 樹冠容積 & 幹周 & 樹幅 & 樹高 & 樹冠容積 \\
\hline \multirow{5}{*}{ A：土壤改良資材 } & & $\mathrm{cm}$ & $\mathrm{cm}$ & $\mathrm{cm}$ & $\mathrm{m}^{3}$ & $\mathrm{~cm}$ & $\mathrm{~cm}$ & $\mathrm{~cm}$ & $\mathrm{~m}^{3}$ & $\mathrm{~cm}$ & $\mathrm{~cm}$ & $\mathrm{~cm}$ & $\mathrm{~m}^{3}$ \\
\hline & バーク堆肥 & 11.5 & 125 & 160 & 1.75 & 23.9 & 208 & 210 & 6.36 & 12.4 & 82.5 & 50.0 & 4.61 \\
\hline & ピートモス & 12.3 & 131 & 178 & 2.10 & 25.3 & 202 & 224 & 6.34 & 13.1 & 71.3 & 46.3 & 4.24 \\
\hline & パーライト & 11.7 & 119 & 171 & 1.71 & 24.4 & 210 & 218 & 6.79 & 12.7 & 90.6 & 46.3 & 5.08 \\
\hline & 無施用 & 11.4 & 133 & 174 & 2.14 & 21.4 & 186 & 188 & 4.58 & 10.1 & 53.8 & 13.8 & 2.43 \\
\hline \multirow{4}{*}{ B : 窒素施肥量 } & 半量 & 11.5 & 121 & 169 & 1.73 & 22.8 & 196 & 210 & 5.71 & 11.4 & 75.0 & 41.3 & 3.97 \\
\hline & 標準量 & 12.2 & 134 & 169 & 2.14 & 25.1 & 211 & 208 & 6.61 & 12.9 & 76.9 & 38.8 & 4.47 \\
\hline & 2 倍量 & 12.0 & 124 & 169 & 1.80 & 24.5 & 194 & 211 & 5.57 & 12.5 & 70.6 & 42.5 & 3.78 \\
\hline & 3 倍量 & 11.1 & 129 & 176 & 2.04 & 22.7 & 204 & 210 & 6.18 & 11.6 & 75.6 & 33.8 & 4.14 \\
\hline \multirow{4}{*}{$\mathrm{C}:$ ゼオライト施用量 } & 無施用 & 11.3 & 120 & 173 & 1.74 & 24.0 & 205 & 214 & 6.41 & 12.6 & 85.0 & 41.3 & 4.67 \\
\hline & 少 & 11.5 & 135 & 171 & 2.19 & 23.1 & 198 & 210 & 5.79 & 11.6 & 62.5 & 38.8 & 3.60 \\
\hline & 中 & 12.1 & 131 & 176 & 2.08 & 24.9 & 200 & 218 & 6.15 & 12.8 & 68.8 & 41.3 & 4.07 \\
\hline & 多 & 11.8 & 121 & 163 & 1.69 & 23.1 & 203 & 198 & 5.71 & 11.2 & 81.9 & 35.0 & 4.02 \\
\hline 分散分析 ${ }^{z}$ & $\begin{array}{c}\text { 土壌改良資材 } \\
\text { 窒素施肥量 } \\
\text { ゼオライト量 }\end{array}$ & $\begin{array}{l}\text { n.s. } \\
\text { n.s. } \\
\text { n.s. }\end{array}$ & $\begin{array}{l}\text { n.s. } \\
\text { n.s. } \\
\text { n.s. }\end{array}$ & $\begin{array}{l}\text { n.s. } \\
\text { n.s. } \\
\text { n.s. }\end{array}$ & $\begin{array}{l}\text { n.s. } \\
\text { n.s. } \\
\text { n.s. }\end{array}$ & $\begin{array}{l}\text { n.s. } \\
\text { n.s. } \\
\text { n.s. }\end{array}$ & $\begin{array}{l}\text { n.s. } \\
\text { n.s. } \\
\text { n.s. }\end{array}$ & $\begin{array}{l}\text { n.s. } \\
\text { n.s. } \\
\text { n.s. }\end{array}$ & $\begin{array}{l}\text { n.s. } \\
\text { n.s. } \\
\text { n.s. }\end{array}$ & $\begin{array}{l}\text { n.s. } \\
\text { n.s. } \\
\text { n.s. }\end{array}$ & $\begin{array}{l}\text { n.s. } \\
\text { n.s. } \\
\text { n.s. }\end{array}$ & $\begin{array}{l}\triangle \\
\text { n.s. } \\
\text { n.s. }\end{array}$ & $\begin{array}{l}\text { n.s. } \\
\text { n.s. } \\
\text { n.s. }\end{array}$ \\
\hline
\end{tabular}

${ }^{\mathrm{z}} \mathrm{F}$ 検定 : $\triangle$ は 10\%の危険率で有意差あり, n.s. は有意差のないことを示す

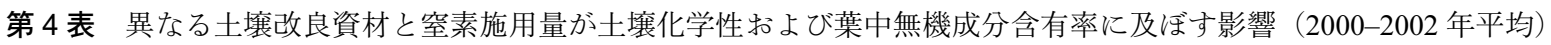

\begin{tabular}{|c|c|c|c|c|c|c|c|}
\hline \multirow{2}{*}{ 要 因 } & \multirow{2}{*}{ 水 準 } & \multicolumn{3}{|c|}{ 土壊化学性 } & \multicolumn{3}{|c|}{ "葉中無機成分含有率 } \\
\hline & & $\mathrm{pH}$ & $\mathrm{EC}$ & $\mathrm{CEC}^{\mathrm{z}}$ & 窒素 & リン & カリウム \\
\hline \multirow{5}{*}{ A：土壌改良資材 } & & & $\mathrm{mS} / \mathrm{m}$ & $\mathrm{me} / 100 \mathrm{~g}$ & $\%$ & $\%$ & $\%$ \\
\hline & バーク堆肥 & 5.03 & 19.9 & $22.4^{\circ}$ & 2.92 & 0.173 & 1.28 \\
\hline & ピートモス & 5.05 & 21.0 & 21.6 & 2.95 & 0.168 & 1.39 \\
\hline & パーライト & 5.07 & 21.0 & 19.7 & 3.02 & 0.179 & 1.37 \\
\hline & 無施用 & 4.96 & 20.8 & 20.4 & 3.12 & 0.172 & 1.27 \\
\hline \multirow{4}{*}{ B : 窒素施肥量 } & 半量 & $6.05 \mathrm{a}^{\mathrm{y}}$ & 10.7 & 20.5 & $2.78 \mathrm{a}$ & $0.208 \mathrm{a}$ & 1.50 \\
\hline & 標準量 & $4.99 \mathrm{~b}$ & 27.3 & 21.0 & $2.98 \mathrm{~b}$ & $0.166 \mathrm{~b}$ & 1.35 \\
\hline & 2 倍量 & $4.72 b$ & 23.4 & 22.1 & $3.12 \mathrm{~b}$ & $0.160 \mathrm{~b}$ & 1.30 \\
\hline & 3 倍量 & $4.34 b$ & 21.3 & 20.6 & $3.14 \mathrm{~b}$ & $0.157 b$ & 1.16 \\
\hline \multirow{4}{*}{ C : ゼオライト施用量 } & $\begin{array}{l}\text { 無施用 } \\
\end{array}$ & 5.24 & 15.4 & $18.6 \mathrm{a}$ & 3.02 & 0.166 & 1.28 \\
\hline & 少 & 4.85 & 19.7 & $17.7 \mathrm{a}$ & 3.01 & 0.179 & 1.35 \\
\hline & 中 & 4.88 & 24.6 & $22.4 \mathrm{ab}$ & 3.01 & 0.171 & 1.33 \\
\hline & 多 & 5.13 & 23.0 & $25.6 \mathrm{~b}$ & 2.97 & 0.174 & 1.36 \\
\hline \multirow{3}{*}{ 分散分析 ${ }^{x}$} & 土䁃改良資材 & n.s. & n.s. & n.s. & n.s. & n.s. & n.s. \\
\hline & 窒素施肥量 & $* *$ & n.s. & n.s. & $* *$ & $*$ & n.s. \\
\hline & ゼオライト量 & n.s. & n.s. & $*$ & n.s. & n.s. & n.s. \\
\hline
\end{tabular}

\footnotetext{
${ }^{\mathrm{z}} \mathrm{CEC}$ の分析は 2000 年のみ実施

${ }^{\mathrm{y}}$ Tukey の多重検定により，同符号間には 5\%水準で有意差のないことを示す

${ }^{\mathrm{x}} \mathrm{F}$ 検定 : **は $1 \%$ ，*は 5\%で有意差あり，n.s. は有意差のないことを示す
}

摘果は 7 月上旬に葉果比 150 を目途に行い, その他の栽 培管理は慣行に従った。

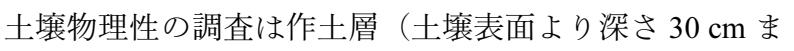
での範囲）について実施し，植付け年（1999年）と 4 年後 （2002 年）の 12 月に実容積法により, pF 1.5 に抢ける三相 分布を調査した。

土壌化学性の調査は, $2000 \sim 2002$ 年の 12 月に作土層の 土䁃を採取し, $\mathrm{pH}$ は水抽出によりガラス電極法で, $\mathrm{EC}$ は $1: 5$ 水抽出法により電気伝導率計 (EC-Meter CM-14P, 東亜
電波工業）で測定した．塩基置換容量（以下 CEC とする） は2000 年のみ, ショーレンベルガー法で分析した.

樹体生育の調查は 1999 年 4 月 2003 年 3 月の成長量 $($ 幹 周, 樹幅, 樹高, 樹冠容積）について行った.

葉中無機成分含有率は $2000 \sim 2002$ 年の 12 月に春葉を採 取し，窒素は NCアナライザー（スミグラフ NC-800，住化 分析センター) で, リンとカリウムは ICP 発光分光分析装置 （SPS3000，セイコーインスルメンッ）でそれぞれ分析した. 果実は $2001 \sim 2003$ 年の 2 月中旬に採取し, 果実收量, 
第 5 表＼cjkstart異なる土畩改良資材と窒素施用量が収量，果実品質に及ぼす影響

\begin{tabular}{|c|c|c|c|c|c|c|c|c|c|c|c|c|c|}
\hline \multirow{3}{*}{ 要 因 } & \multirow{3}{*}{ 水 準 } & \multirow{2}{*}{\multicolumn{3}{|c|}{ 果実収量（kg） }} & \multicolumn{9}{|c|}{ 果実品質 } \\
\hline & & & & & \multicolumn{3}{|c|}{ 果皮率（\%） } & \multicolumn{3}{|c|}{ 糖度（Brix $\left.{ }^{\circ}\right)$} & \multicolumn{3}{|c|}{ 酸度（\%） } \\
\hline & & 2001 & 2002 & 2003 & 2001 & 2002 & 2003 & 2001 & 2002 & 2003 & 2001 & 2002 & 2003 \\
\hline \multirow{4}{*}{ A：土畩改良資材 } & バーク堆肥 & 6.5 & 13.5 & 16.6 & 27.0 & 24.2 & 25.8 & 14.5 & 15.3 & 17.4 & 1.35 & 1.05 & 1.23 \\
\hline & ピートモス & 8.2 & 9.3 & 14.2 & 26.7 & 22.2 & 24.5 & 15.0 & 15.9 & 17.4 & 1.33 & 1.03 & 1.15 \\
\hline & パーライト & 8.2 & 8.7 & 14.8 & 26.1 & 25.2 & 25.2 & 14.2 & 16.0 & 17.9 & 1.25 & 1.03 & 1.19 \\
\hline & 無施用 & 5.2 & 7.8 & 8.3 & 24.3 & 24.0 & 25.7 & 14.8 & 17.1 & 18.0 & 1.34 & 1.26 & 1.24 \\
\hline \multirow{4}{*}{ B : 窒素施肥量 } & 半量 & 5.0 & 8.9 & 12.0 & 22.7 & $19.0 \mathrm{a}$ & $21.8 \mathrm{a}$ & 14.0 & 16.0 & $16.3 \mathrm{a}$ & $1.25 \mathrm{ab}$ & 1.08 & 1.11 \\
\hline & 標準量 & 6.4 & 10.8 & 13.3 & 23.5 & $23.5 \mathrm{ab}$ & $24.9 \mathrm{ab}$ & 14.2 & 15.6 & $17.9 \mathrm{~b}$ & $1.23 \mathrm{~b}$ & 1.01 & 1.20 \\
\hline & 2 倍量 & 6.8 & 10.6 & 15.7 & 28.2 & $26.6 b$ & $27.7 b$ & 15.2 & 16.1 & $18.4 b$ & $1.34 \mathrm{ab}$ & 1.14 & 1.28 \\
\hline & 3 倍量 & 9.9 & 9.0 & 12.9 & 29.7 & $26.7 \mathrm{~b}$ & $26.9 \mathrm{~b}$ & 15.1 & 16.6 & $18.1 \mathrm{~b}$ & $1.45 \mathrm{a}$ & 1.15 & 1.22 \\
\hline \multirow{4}{*}{ C : ゼオライト施用量 } & 無施用 & 9.0 & 6.6 & 12.6 & 27.6 & 24.0 & 25.5 & 14.8 & 15.6 & 17.9 & 1.39 & 1.08 & 1.16 \\
\hline & 少 & 6.2 & 8.6 & 14.3 & 25.7 & 24.7 & 26.5 & 14.6 & 16.2 & 17.9 & 1.33 & 1.09 & 1.28 \\
\hline & 中 & 4.9 & 11.6 & 12.5 & 24.2 & 23.9 & 23.4 & 14.9 & 16.2 & 17.0 & 1.26 & 1.16 & 1.15 \\
\hline & 多 & 8.1 & 12.5 & 14.5 & 26.5 & 23.1 & 25.8 & 14.2 & 16.4 & 17.9 & 1.27 & 1.06 & 1.22 \\
\hline \multirow{3}{*}{ 分散分析 ${ }^{y}$} & 土䁃改良資材 & n.s. & n.s. & $\triangle$ & n.s & n.s & n.s. & n.s & n.s & n.s & n.s & n.s & n.s \\
\hline & 窒素施肥量 & n.s. & n.s. & n.s. & $\triangle$ & $*$ & $* *$ & $\triangle$ & n.s & $* *$ & $*$ & n.s & n.s \\
\hline & ゼオライト量 & n.s. & n.s. & n.s. & n.s. & n.s & $\triangle$ & n.s & n.s & n.s & n.s & n.s & n.s \\
\hline
\end{tabular}

${ }^{\mathrm{z}}$ Tukey の多重検定により，同符号間には 5\%水準で有意差のないことを示す

${ }^{\mathrm{y}} \mathrm{F}$ 検定 : **は $1 \%$ ，*は 5\%, $\triangle$ は 10\%で有意差あり，n.s. は有意差のないことを示す

第 6 表 異なる土䁃改良資材と窒素施用量が収穫時の果皮色に及ぼす影響

\begin{tabular}{|c|c|c|c|c|c|c|c|c|c|c|c|c|c|}
\hline \multirow{2}{*}{ 要 因 } & \multirow{2}{*}{ 水 準 } & \multicolumn{3}{|c|}{ L*值 } & \multicolumn{3}{|c|}{ a*值 } & \multicolumn{3}{|c|}{ b*值 } & \multicolumn{3}{|c|}{$\mathrm{a}^{*} / \mathrm{b} * \times 100$} \\
\hline & & 2001 & 2002 & 2003 & 2001 & 2002 & 2003 & 2001 & 2002 & 2003 & 2001 & 2002 & 2003 \\
\hline \multirow{4}{*}{ A : 土壤改良資材 } & バーク堆肥 & 63.0 & 61.0 & 60.1 & 32.7 & 29.8 & 32.5 & 65.5 & 60.8 & 61.3 & 49.8 & 49.0 & 52.9 \\
\hline & ピートモス & 63.1 & 61.5 & 60.2 & 30.6 & 30.0 & 32.1 & 64.5 & 62.2 & 61.2 & 47.4 & 48.3 & 52.5 \\
\hline & パーライト & 63.0 & 60.7 & 59.8 & 31.1 & 30.3 & 32.4 & 65.2 & 60.7 & 60.5 & 47.7 & 49.9 & 53.5 \\
\hline & 無施用 & 63.5 & 60.4 & 59.8 & 31.5 & 30.5 & 32.2 & 64.5 & 62.3 & 60.8 & 48.9 & 49.0 & 52.9 \\
\hline \multirow{4}{*}{ B : 窒素施肥量 } & 半量 & 63.4 & 62.9 & 61.2 & 31.9 & 30.9 & 34.5 & 64.7 & 65.1 & 62.9 & 49.3 & 47.5 & 54.8 \\
\hline & 標準量 & 63.1 & 61.0 & 60.0 & 31.6 & 30.3 & 32.7 & 64.7 & 61.4 & 61.1 & 48.9 & 49.5 & 53.5 \\
\hline & 2 倍量 & 63.2 & 60.2 & 59.4 & 32.7 & 29.2 & 30.6 & 66.3 & 59.5 & 59.7 & 49.2 & 49.1 & 51.3 \\
\hline & 3 倍量 & 63.0 & 59.5 & 59.4 & 29.7 & 30.1 & 31.4 & 64.1 & 60.0 & 60.1 & 46.4 & 50.1 & 52.2 \\
\hline \multirow{4}{*}{$\mathrm{C}$ : ゼオライト施用量 } & 無施用 & 63.4 & 60.6 & 59.5 & 30.7 & 30.6 & 32.6 & 64.5 & 62.3 & 60.0 & 47.6 & 49.2 & 54.3 \\
\hline & 少 & 63.2 & 60.7 & 59.9 & 31.3 & 29.9 & 31.9 & 64.4 & 60.2 & 60.4 & 48.5 & 49.7 & 52.8 \\
\hline & 中 & 62.7 & 60.8 & 60.8 & 33.1 & 29.9 & 32.2 & 66.4 & 60.9 & 62.6 & 49.9 & 49.1 & 51.4 \\
\hline & 多 & 63.3 & 61.4 & 59.8 & 30.8 & 30.2 & 32.4 & 64.4 & 62.5 & 60.8 & 47.8 & 48.2 & 53.3 \\
\hline \multirow{3}{*}{ 分散分析 ${ }^{\mathrm{z}}$} & 土壤改良資材 & n.s & $\mathrm{n} . \mathrm{s}$ & n.s. & n.s & n.s & n.s & n.s & n.s & n.s & n.s & n.s & n.s \\
\hline & 窒素施肥量 & n.s & $*$ & $* *$ & n.s & $*$ & $* *$ & n.s & $\triangle$ & $*$ & $*$ & n.s & $*$ \\
\hline & ゼオライト量 & n.s. & $\mathrm{n} . \mathrm{s}$ & $* *$ & n.s & n.s & n.s & n.s & n.s & $*$ & $\mathrm{n} . \mathrm{s}$ & $\mathrm{n} . \mathrm{s}$ & $\triangle$ \\
\hline
\end{tabular}

${ }^{\mathrm{z}} \mathrm{F}$ 検定 : **は 1\%，*は5\%， *は 10\%で有意差あり，n.s. は有意差のないことを示す

果実品質（果皮率，糖度，酸度，果皮色）を調査した。果 皮色は測色色差計（TC-1500-MC，東京電色）で測定した.

根量調査は植付け 4 年後の 2002 年 8 月下旬に行い, 掘取 り法 (主幹加 $30 \sim 120 \mathrm{~cm}$, 角度 $60^{\circ}$ の扇型, 深さ $30 \mathrm{~cm}$, 3 か所 / 樹 (第 2 図) ) により, 水で洗淨後, 山内（1996）の 分類に従い, 細根（直径 $2 \mathrm{~mm}$ 以下）と中小根（直径 2 $20 \mathrm{~mm}$ ) に分け, $105^{\circ} \mathrm{C}$ で 3 日間以上乾燥後, 乾物重を計測 した。また，掘り取った細根から新鮮重で $10 \mathrm{~g}$ を採取し， $\mathrm{O}_{2}$ アップテスター $\left(\mathrm{O}_{2}\right.$ アップテスター $10 \mathrm{~B}$, タイテック $)$ により細根の呼吸量を測定するとともに実体顕微鏡 (15倍)
で細根の状態を観察した。

\section{結果}

土壌物理性に及ぼす処理の影響は，植付け初年度および 4 年後に扣いて, ともに土䁃改良資材の種類についてみら れ，いずれの土畩改良資材も気相率を増加，固相率を減少 させた。 バーク堆肥とピートモスで特に効果が高かった (第 2 表).

樹体生育量に及ぼす影響は土㖶改良資材の種類について みられ，バーク堆肥，ピートモス，パーライトのいずれか 
第 7 表 異なる土壤改良資材と窒素施用量が根量と根活性に及ぼす影響

\begin{tabular}{|c|c|c|c|c|c|}
\hline \multirow{2}{*}{ 要 因 } & \multirow{2}{*}{ 水 準 } & \multicolumn{3}{|c|}{ 根量（乾物重） } & \multirow{2}{*}{$\begin{array}{l}\text { 根活性 } \\
\text { 呼吸量 }\end{array}$} \\
\hline & & 細根 & 中小根 & 合計 & \\
\hline \multirow{5}{*}{ A : 土壤改良資材 } & & $\mathrm{g}$ & $\mathrm{g}$ & $\mathrm{g}$ & $\mu \mathrm{molO}_{2} / \mathrm{dw} \cdot \mathrm{g} / \mathrm{h}$ \\
\hline & バーク堆肥 & 103.8 & 33.1 & 137.0 & 18.5 \\
\hline & ピートモス & 95.7 & 34.7 & 130.4 & 16.2 \\
\hline & パーライト & 89.4 & 38.6 & 128.0 & 16.5 \\
\hline & 無施用 & 51.3 & 17.8 & 69.1 & 15.2 \\
\hline \multirow{4}{*}{ B : 窒素施肥量 } & 半量 & $92.4 \mathrm{ab}^{\mathrm{z}}$ & 34.2 & 126.6 & 17.2 \\
\hline & 標準量 & $122.9 \mathrm{a}$ & 37.9 & 160.8 & 17.3 \\
\hline & 2 倍量 & $71.2 \mathrm{ab}$ & 23.5 & 94.8 & 16.4 \\
\hline & 3 倍量 & $53.6 \mathrm{~b}$ & 28.7 & 82.3 & 15.3 \\
\hline \multirow{4}{*}{ C: ゼオライト施用量 } & 無施用 & 81.0 & 22.9 & 103.9 & 17.0 \\
\hline & 少 & 71.7 & 28.1 & 99.8 & 15.3 \\
\hline & 中 & 99.6 & 45.3 & 144.9 & 18.2 \\
\hline & 多 & 87.9 & 27.9 & 115.8 & 15.8 \\
\hline \multirow{3}{*}{ 分散分析 ${ }^{y}$} & 土壤改良資材 & $\triangle$ & n.s. & n.s. & n.s. \\
\hline & 窒素施肥量 & $*$ & n.s. & n.s. & n.s \\
\hline & ゼオライト量 & n.s. & n.s. & n.s. & n.s. \\
\hline
\end{tabular}

${ }^{\mathrm{z}}$ Tukey の多重検定により，5\%の危険率で同一符号間に有意差のないことを示す

${ }^{\mathrm{y}} \mathrm{F}$ 検定 : * $5 \%, \triangle$ は 10\%で有意差あり，n.s. は有意差のないことを示す

第 8 表 細根量の分散分析表

\begin{tabular}{|c|c|c|c|c|c|c|c|c|c|c|}
\hline \multirow{2}{*}{ 要 因 } & \multicolumn{4}{|c|}{ 水準に付与される係数 } & \multirow{2}{*}{$\begin{array}{l}\text { 平方和 } \\
\text { (SS) }\end{array}$} & \multirow{2}{*}{ 自由度 } & \multirow{2}{*}{$\begin{array}{l}\text { 分散 } \\
(\mathrm{MS})\end{array}$} & \multirow{2}{*}{\multicolumn{2}{|c|}{ F 值（確率） }} & \multirow{2}{*}{$\begin{array}{c}\text { 寄与率 } \\
(\%)\end{array}$} \\
\hline & 1 & 2 & 3 & 4 & & & & & & \\
\hline A：土塞改良資材 & $18.8^{\mathrm{z}}$ & 10.6 & 4.3 & -33.7 & 6487 & 3 & 2162 & 3.32 & $(-0.093)$ & 20.0 \\
\hline B : 窒素施肥量 & $7.4 \mathrm{ab}^{\mathrm{y}}$ & $37.9 \mathrm{a}$ & $-13.8 \mathrm{ab}$ & $-31.5 b$ & 10683 & 3 & 3561 & $5.48^{* \mathrm{x}}$ & $(0.037)$ & 38.4 \\
\hline \multirow{2}{*}{$\begin{array}{l}\mathrm{C}: \text { : オライト量 } \\
\mathrm{e}: \text { 誤差 }\end{array}$} & -4.1 & -13.4 & 14.6 & 2.9 & 1667 & 3 & 556 & 0.86 & & 0.0 \\
\hline & & & & & 3900 & 6 & 650 & & & 41.6 \\
\hline 合計 & & & & & 22737 & 15 & & & & 100 \\
\hline
\end{tabular}

$\mathrm{z}$ 総平均は $85.1 \mathrm{~g}$

${ }^{\mathrm{y}}$ Tukey の多重比較により，同符号間には 5\%の危険率で有意差のないことを示す

${ }^{\mathrm{x}} \mathrm{F}$ 検定により，*は5\%の危険率で有意差のあることを示す

を施用することで無施用区より樹高の増加量が大きくなっ た（第 3 表).

土壌 $\mathrm{pH}$ に及ぼす影響は，窒素施肥量で認められ，標準 区, 2 倍量区, 3 倍量区で, 半量区より $\mathrm{pH}$ は有意に低く なった。しかし，EC 值に各処理間の差は認められなかっ た（第 4 表）。また，ゼオライトを施用することで CEC は 高くなった.

葉中無機成分は, 窒素施肥量の半量区で他の区より窒素 含有率が低く，リン含有率が高くなった（第 4 表）.

果実収量に及ぼす影響は2003年の土垬改良資材について みられ，バーク堆肥，ピートモス，パーライトを施用する ことで，無施用区より収量が多くなった.

果実品質には窒素施肥量の影響が認められ, 窒素施肥量 が 2 倍量区，3 倍量区では，果皮率が半量区，標準量区よ り高くなった。 また，糖度は 2001 年と 2003 年で標準量区 は半量区より高くなった. 酸度は 2001 年に 3 倍量区で高く なったが，その他の年では差が小さかった（第 5 表）。果皮
色は施肥量により色調が異なり, 窒素施肥量が多いほど $\mathrm{L}^{*}$ 值，a*值，b*值，a*/b*×100 が低くなった（第 6 表）.

植付け 4 年後の細根量に及ぼす影響は土壤改良資材の種 類と窒素施肥量についてみられ，土壌改良資材を施用する と細根量が増加し，窒素施肥量が多い注ど細根量は減少し た（第 7 表）.

細根を実体顕微鏡で観察したところ，施肥量が少ない窒 素半量区および標準量区では細根が白く，量も多かった (第 3 図 A)。しかし, 窒素施肥量の 3 倍量区では細根の褐 変と腐敗がみられ（第 3 図 B ）, 細根の表皮拈よび皮層が崩 壊し，中心柱のみのものが多いことが確認された。

根の呼吸量については，統計的な有意差はみられな かった。

細根量に及ぼす影響について，寄与率を算出した結果， 窒素施肥量の寄与率が $38.4 \%$ で最も高く，最も強い影響を 及汇していた（第 8 表）。また，土㥽改良資材の寄与率も 20.0\%であった。 


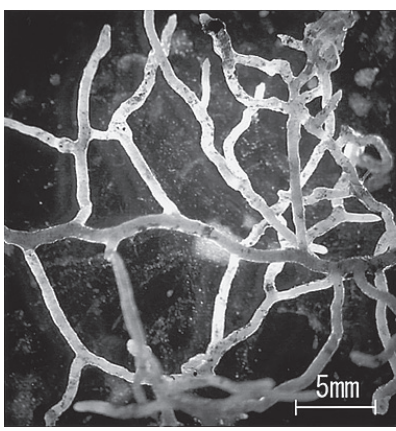

(A)

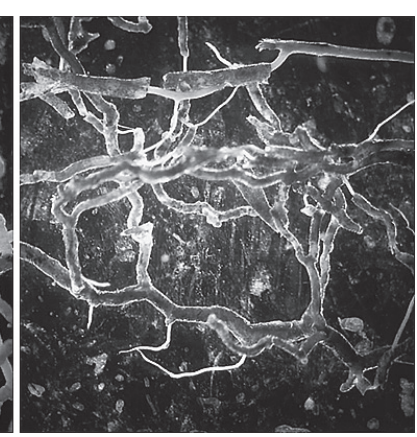

(B)
第 3 図 異なる窒素施肥量が細根に及ぼす影響

(A) 窒素半量区

(B) 窒素 3 倍量区

分散分析表から，細根を最も増加させる組合せは，バー ク堆肥 + 窒素標準量施用で, $133.6 \mathrm{~g}$ の細根の乾物重が期待 され, 最も細根を減少させる組合せは, 土䁃改良資材無施 用 + 窒素 3 倍量施用で $19.9 \mathrm{~g}$ が期待された.

\section{考察}

バーク堆肥とピートモスは土壌の膨潤化, 保水性の向上, パーライトは透水性や保水性の向上の効果があるとされて いる（尾和，1996; 岩間，1996），そこで窒素成分の含まれる 有機物の土壌改良資材としてバーク堆肥, 窒素成分が極めて 少ない有機物の土壤改良資材としてピートモス, 窒素成分の ない無機質の土壤改良資材としてパーライトを選んだ.

有機物などの施用によるカンキッ園の土壌物理性改善効 果は過去にも報告されている（岩切ら，1988; 峯・小田, 1984). 今回の試験で使用した, バーク堆肥, ピートモス, パーライトは, いずれも土壌の固相率を低くし，4年後に 扣いても土䁃物理性の改善効果が認められた（第 2 表）.

岩切ら（1988）は山中式硬度計で 21 以上, 古河（1972）, 小野ら（1986）は24～25 以上で細根量がみられなくなっ たことを報告している. 一方，峯・小田（1984）により， 細根の分布が少ない層では粗孔隙が $10 \%$ 以下, 固相 $50 \%$ 以 上を示す土壌が多かったと報告されている. また, 古河 （1972）は主として毛管孔隙率と固相率が，ウンシュウミカ ン樹の根の伸長に関与すると推定している. これらのこと から本研究においても, 土壤改良資材の施用が固相率を低 下させ，その結果 ‘不知火’ の細根量を増加させたものと 考えられた。

窒素の施肥量とウンシュウミカンの細根量との関係は, 施肥量が多い葟ど根量が少なくなることが示されており (金子ら，1970; 西田, 1982; 小笠原ら，1967), 岡島ら (1998) も ‘不知火’の施肥量が標準量の 1.5 倍で細根が少なくなっ たことを報告している. 本研究に扣いても, 施肥量が増加 するほど減少した (第 6 表)。 また, 掘り取った細根の状態 は, 施肥量の少ない区では白いものの, 施肥量の多い区で は褐色の細根が多くみられた（第 3 図）。
ウンシュウミカン園では土壌 $\mathrm{pH}$ が 4 以下になると根の 生育が劣ること（古河，1972）が報告されているが，今回 の試験では，すべての区で $\mathrm{pH} 4$ 以上であることから，別の 原因が考えられた。

一般に塩類が集積した土壤では，作物の生育阻害や生理 障害が発生し，その原因として土塞溶液の高浸透压による 作物の給水阻害（浸透圧ストレス）扎よび特定のイオンの 過剰害（イオンストレス）があり，これらは，根の生育・ 機能阻害として現れることが示されている（山崎，1998）. 一方, 窒素の施肥量を増加させると土壌中の硝酸イオン濃 度を増加させ, EC 值を高くすることも報告されている（大 西ら，1972）。土壤溶液の浸透圧は，EC 值に対応し高まる （土壤標準分析・測定法委員会，1986）。本試験では塩類集 積や高いEC 值は確認されなかったものの (第 4 表), 多量 の窒素施肥が一時的に土壇溶液中の硝酸イオン濃度を高 め, 浸透圧ストレスにより細根量が減少した可能性があ る. 本試験では, 土壤の EC 值に処理間の差がみられな かった理由として，土壌を採取した時期が 12 月であり，10 月の施肥から 2 か月経過しているため, 土塞中の硝酸イ才 ン量が低下していたのかもしれない.

土壌物理性と土畩化学性が細根量に及ぼす影響は, 第 1 要因として土壤の物理性, 土壤化学性（塩基バランス）は 2 次的要因であることが示されている（峯・小田，1984）. しかし, 今回の細根量に対する影響は, 過剰な窒素の施肥 が，土壌改良資材施用による物理性改善効果より高かっ た。これは, 試験に打ける土壤改良資材施用と窒素施肥量 の影響の度合いを比較すると, 窒素施肥量の方がより大き かったため, 結果の変動幅が大きくなり, 寄与率が高く なったためと考光られる (第 8 表). 試験 4 年目の窒素施肥 量 3 倍量区は, 年間窒素施肥量で 1 ha 当たり $759 \mathrm{~kg}$ であ る. また，土壤改良資材の施用量は生産現場で施用されて いる量に近い。これらのことから, 細根量を増加させる目 的で, 土壤改良資材を施用しても, 窒素施肥量が過剰であ れば，後者の影響が強く現れ，細根量は少なくなったと推 察された.

窒素施肥量とカンキッ果実品質については，いくつかの 報告があり（石原，1982; 坂本・奥地， 1969; 高辻，1987）, 窒素施肥量が増加するに従い，果実が小さくなる，成熟期 の果皮の着色が遅れ，緑色が強くなる，果皮が厚くなるな ぞがある. 果汁の酸度については, 窒素量の増加に伴い, 高くなる報告と差が認められない報告があり，また糖度も 増加と減少の報告がある。 今回, “不知火’についても, 窒 素施肥量が果皮率と果皮色に影響を及ぼすことが明らかに なった (第 5,6表). ‘不知火’の生産現場では, 酸高果実の 生産が問題であり，細根量が少ない園ほどその傾向が強い (高原, 1999). 本試験では細根量は少なくなったものの, 酸 度は差が無かった（第 5, 7 表）. 夏季に土壤が乾燥すると， 酸度の高い果実が生産されやすいが, 適度にかん水するこ とで，それが抑制できることが示されている（平山ら， 
1996). 本試験では7～9月の降雨がない週には1週間に2 3 回かん水した. このことが, 全体に酸度が低くなり, 差が みられなかった理由と考えられた.

ゼオライトは土畩中の CECを高くし, 陽イオンの流亡を 抑制する土䁃改良資材であることから（長野，1996）, 本研 究の C 要因として取り上げ, 施用量が土䁃化学性, 樹体生 育, 葉中無機成分含有率, 果実品質, 細根量に及ぼす影響 をみた。しかし, 土䁃中の CECを増加させる効果は認めら れたものの，他には影響がみられなかった（第 $3 \sim 7$ 表）. また，それぞれの測定項目へのゼオライト施用量の寄与率 は土壤改良資材, 室素施肥量に比較し低かったこと（第 8 表)から, 本試験に扣けるゼオライト施用の影響は小さかっ たと考えられた。

\section{摘 要}

樹勢の弱い中晚生カンキッ“不知火’に対して土㙥改良 資材の施用と窒素施肥量の違いが樹体生育, 土壤物理性, 果実品質, 細根量に及ぼす影響を調査した。 土壌改良資材 であるバーク堆肥，ピートモス，パーライトを施用するこ とで, 土壤物理性が改善され, 細根量が増加した。 窒素施 肥量を多くすると，細根量は減少し，果皮率と糖度が高く なる傾向であった。 土壌改良資材を施用しても, 窒素施肥 量が多いと, 細根量は減少し, その寄与程度は窒素施肥量 が土壌改良資材施用の約 2 倍であった。これらの結果より， “不知火’の細根を増加させ，樹勢を良くするためには，土 壤改良資材を施用した上で，過剩な窒素施用は避ける必要 があるものと考えられた。

謝 辞 本調査結果の取りまとめにおいて, 御校閲頂い た千葉大学園芸学部助教授の小原 均博士, 静岡県柑滳試 験場の吉川公規主任研究員, 統計手法の御指導頂いた, 独 立行政法人農業工学研究所の執行盛之元農地整備部長に対 し，深謝の意を表する，また，本調査にあたり，多大なご 協力を頂いた若杉 勲元技能長にお礼申し上げる.

\section{引用文献}

土䁃標準分析・測定法委員会. 1986. 土壤標準分析・測定法. p. 74-76. 博友社. 東京.

平山秀文・藤田賢輔 - 磯部 暁 - 重岡 開. 1996. 不知火 の品種特性と生産安定技術の確立. 熊本農研七研報. 5: 125-140.

石原正義. 1982. 果樹の栄養生理. p. 79-86. 農文協. 東京. 岩切徹・松瀬政司 - 小野 忠. 1988. 果樹園に打ける有 機物施用効果の解析. 第 5 報. 堆肥施用ウンシュウミ カン樹の根群分布. 佐賀果樹研報. 10: 35-46.

岩間秀矩. 1996. パーライト. p. 152-157. 農林水産省農産

園芸局農産課監修. 土壌改良と資材. 土壤保全調査事 業全国協議会. 東京.

加美 豊・井上久雄・藤原文孝. 1998. 八ウス栽培におけ
るカンキッ“不知火”の着果及び炭酸ガス施用が樹体 生長に及ぼす影響. 園学雑. 67 (別 2) : 193.

河瀬憲次. 1999a. デュポン（不知火）の生い立ち. p. 10 13. 河瀬憲次編著. デュポンをつくりこなす. 農文協. 東京.

河瀬憲次. 1999b. 根群の生育と樹勢強化対策. p. 111-116. 河瀬憲次編著. デュポンをつくりこなす. 農文協. 東京.

金子 衛・鈴木鉄男・田中 実. 1970. 温州ミカンの生育 と結実ならびに土壤の化学性に及ぼす多肥の影響. 愛 知農総研 B. 園芸 $2: 1-10$.

北園邦弥・平山秀文・磯部 暁・河瀬憲次. 2000. カンキ ツの樹勢調節に関する研究（第 1 報）着果負担及びユ リン系化合物処理と根群の発達について. 熊本農研七 研報. 9: 104-108.

古河 汎. 1972. 温州ミカン園に拈ける下層土の物理性に 関する研究. 四国農試報. 25: 119-232.

峯 浩昭・小田真男. 1984. 温州ミカン園にお打る表層及び 下層土改良（第 1 報）オガクズ入り鶏らんの連用と深 耕が根群分布に及ぼす影響. 大分柑橘試研報. 2: 51-68. 長野間宏. 1996. ゼオライト．p. 135-144. 農林水産省農産 園芸局農産課監修.土壤改良と資材. 土塞保全調査事 業全国協議会. 東京.

西田和男. 1982. 温州ミカンの根群分布と土㙋の化学性.

広島果試研報. 8: 1-11.

小笠原佐代市・中井 九・伊藤晴充. 1967. 温州みかんの 施肥量に関する試験. 山口農試報. 20: 55-60.

岡島量男・相川博志・長田芳郎・土田通彦・磯田隆晴. 1998. カンキッ ‘不知火’の施肥法. 熊本農研七研報. 7: 77-87. 岡島量男. 1999. 土壌管理と有機物施用. p. 77-80. 河瀬憲 次編著. デュポンをつくりこなす. 農文協. 東京.

小野祐幸・岩垣 功・高原利雄. 1986. カンキッの根群分布 と葉の着生との関係. 果樹試報. D8: 25-36.

尾和尚人. 1996. 地力増進法指定資材. p. 79-109. 農林水 産省農産園芸局農産課監修。土壌改良と資材。土壌保 全調査事業全国協議会. 東京.

大西和彦・坂本辰馬・丹原一寛. 1972. カンキッ園の肥料分 の残留と根群の濃度障害. 園学四国支部要旨. p. 7.

坂本辰馬・奥地 進. 1969. 温州ミカン果実の酸, 可溶性固 形物に及ぼすチッソ栄養の影響. 園学雑. 38: 301-308. 高原利雄. 1999. 品種特性とつくりこなしの着眼点. p. 14 27. 河瀬憲次編著. デュポンをつくりこなす. 農文協. 東京.

高辻豊二. 1987. 施肥の基本と施肥設計．p. 145-154. 農業 技術体系 果樹 1 カンキッ. 農文協. 東京.

山内 章. 1996. 林木の根系. p. 90. 山内 章編. 植物根 系の理想型. 博友社. 東京.

山崎浩道. 1998. 塩類集積と根. p. 242-244. 根の辞典編集 委員会編. 根の辞典. 朝倉書店. 東京. 